\title{
Goat's rue (Galega orientalis Lam.), a potential pasture legume for temperate conditions
}

\author{
EERO VARIS \\ University of Helsinki, Department of Plant Husbandry, \\ SF-00710 HELSINKI, Finland
}

\begin{abstract}
In this paper, a perennial legume Galega orientalis Lam. (goat's rue), is presented. This unselected forage legume originating from regions with a Mediterranean climate, grows well in North-European conditions in Finland. It seems to be very persistent and produces yields that equal or even exceed those of red clover in quantity and quality.

The trials on management practices and feeding carried out at the University of Helsinki are reported here. The research will be continued on mass selection for low alcaloid and fiber contents, seed production and use of grass-mixtures for making hay or silage.
\end{abstract}

Index words: Galega orientalis, goat's rue, pasture legume

\section{Introduction}

Intensification of the use of legumes has been widely studied in Finland during recent years. In addition to attempts to improve the management of traditional crops, such as red clover, pea and field bean, research has been devoted to potential new legume species. Of the few newcomers that seem to be adapted to the northern Finnish climate, one of the most promising appears to be Galega orientalis Lam. (goat's rue). Its better known relative, G. officinalis L. (goat's rue, French lilac), is used as an ornamental and medicinal plant, and occurs as a weed.

Goat's rue was brought to Finland from Estonia, where its cropping and quality char- acteristics have been widely studied from the beginning of the 1970's. At the Department of Plant Husbandry of the University of Helsinki, field trials were started in 1978. At the same time the Departments of Microbiology and Animal Husbandry commenced microbiological and feeding studies. The research projects reported here were led by the author and mainly carried out by P. Kansanen and T. Kortesmaa at the Department of Plant Husbandry, by K. Lindström at the Department of Microbiology and by M. Jauho at the Department of Animal Husbandry. Financial support was given by the Finnish Academy of Sciences in 1979-1981 and by the SITRA Foundation in 1981-1984.

In this paper, the botanical characteristics, 
results of crop management trials and feeding characteristics of the plant are given. The experience obtained in Finland is supplemented with reports found in the literature. More detailed results have been reported in Finnish (Kansanen 1983, Lattu 1983, Jauho 1984, and MÄKÄRÄINEN et al. 1985).

\section{Origin and distribution}

The legume genus Galega is generally considered to consist of six species indigenous to the warm temperate regions from Mediterranean Europe to Iran, and the mountain regions of tropical East Africa. The origin of the plant is not certain, but it is thought to have been brought to Europe from the Near East by Arabs or Hungarians. Later, G. officinalis was taken to South America and New Zealand, where it became a harmful weed (HEGI 1924, Tutin et al. 1968, Milne-Redhead and Polhill 1971, Willis 1973).

\section{Botanical characteristics}

G. orientalis develops into a bush with $10-18$ stems of a height of $50-150 \mathrm{~cm}$. The stem is hollow and branches in the upper part. The stipules are ovate and $1-1.5 \mathrm{~cm}$ long. The numerous leaves are $14-25 \mathrm{~cm}$ long and consist of 9-15 oblong acuminate leaflets $3-6 \mathrm{~cm}$ long. There are a few pubescent flower clusters on the stem, containing 2025 blue-violet, sometimes white, $1-\mathrm{cm}$ long flowers.

Goats's rue is a cross-pollinating plant, flowering for 18-25 days. The pods are 2$4 \mathrm{~cm}$ long and contain 3-7 kidney-shaped seeds. The weight of a thousand seeds is 5.5$9.0 \mathrm{~g}$. The seeds are yellowish green in colour, later light brown (Komarov 1963, Tutin et al. 1968, RaIG 1980).

Goat's rue has a long root system, reaching to a depth of $60-80 \mathrm{~cm}$. In the seeding year it consists of the main root and its laterals. In the early autumn, $2-18$ stolons grow from the root collar, first extending horizontally under the soil surface and then turning up- wards to form new shoots. The underground stolons are important, for new goat's rue plants develop from wintering stolon buds. When the parent plant dies, the shoots that have developed from the underground stolons grow additional roots and become independent plants. With the help of the stolons, a thinned plant stand can attain a normal growing density of $400-450 \mathrm{stems} / \mathrm{m}^{2}$ (RAIG 1980).

Goat's rue is able to fix nitrogen in association with Rhizobium bacteria. The nodules can be separated into three groups according to their shape. Two kinds of nodules can be found in the top soil, namely, unbranched oval and branched nodules. Deeper in the soil, only smaller, flat nodules occur. The number of nodules ranges between 400 and 1500/plant depending on the growth factors and soil conditions (Proctor and Moustafa 1962).

The Rhizobium which nodulates Galega species is not related to the major groups of rhizobia infecting other legumes and forms a specific taxonomic group within the genus. Although the Rhizobium of pea (Pisum sativum) infects the roots of goat's rue, the symbiosis is ineffective (LiNDSTRÖM et al. 1983). As nitrogen fixation is closely related to the metabolism of the host plant, the air temperature and other growth factors greatly influence the activity of the nodules (LINDSTRÖM 1984).

\section{Utilization}

\subsection{Forage legume}

In the 19th century $G$. orientalis was little known as a crop plant, except in Russia, where it was appreciated as a source of honey. Cropping experiments started in the 1920's in Russia. In the beginning of the 1970's goat's rue seeds were collected from different parts of the Soviet Union and more intensive research was started in several places (RAIG 1980).

\subsection{Soil improvement}

Goat's rue is suitable for soil improvement 
and green manuring. As it has a large root system, it enriches the soil with large quantities of good organic matter. Thus, the plant improves both the texture and the nitrogen balance of the soil. In Estonia the favourable effect of goat's rue was observed to last for $2-3$ years. In a 30-cm-thick soil layer the root system of goat's rue left 3.8 times more dry matter, 3.6 times more potassium, 2.7 times more calcium and 5.0 times more nitrogen than the root system of timothy (RAIG 1980). In addition, goat's rue was reported to reduce plant diseases, pests and weeds, though couch grass (Agropyron repens) proved able to compete with goat's rue (RAIG 1980).

\subsection{Honey plant}

Goat's rue is pollinated by insects and is attractive to both honeybees and bumblebees. Because of its early flowering, it complements the selection of honey plants in early summer. In seed production experiments, it was found that placing bee hives in the field increased seed yields from $180-400 \mathrm{~kg} / \mathrm{ha}$ to $670 \mathrm{~kg} / \mathrm{ha}$ in unfavourable pollination conditions (RAIG 1980).

\section{Growth requirements}

\subsection{Light}

Goat's rue is very intolerant of shading in the sowing year. Shading also impairs the overwintering ability, makes the stand thinner and improves weed growth. Because goat's rue has a high light demand, the sward is usually established without a cover crop. Goat's rue is sensitive to shading in later years as well. On the other hand, its large photosynthesizing surface and long growth period allow effective use of radiation and result in abundant dry matter yields (RAIG 1980).

The optimum plant density for vegetative production is $400-450$ shoots $/ \mathrm{m}^{2}$. In seed production, a thinner stand is recommended, since goat's rue needs more light for abundant flowering and seed formation (RAIG 1980).

\subsection{Temperature}

G. orientalis germinates at $5-6^{\circ} \mathrm{C}$, but the optimum temperature is $10-12^{\circ} \mathrm{C}$ (RAIG 1980). It can endure an air temperature of $-40^{\circ} \mathrm{C}$ under snow cover and $-20^{\circ} \mathrm{C}$ in a bare field. During the growing season, the leaves tolerate -5 to $-7^{\circ} \mathrm{C}$ without any reduction in yield. Low spring temperatures, however, can decrease the growth and nitrogen fixation (RAIG 1980).

\subsection{Water}

G. orientalis resists drought fairly well. Its water requirements are said to be between those of lucerne and red clover. High ground water and flooding are harmful, but goat's rue can withstand spring floods reasonably well for up to 12-18 days (RAIG 1980).

The strong root system permits good utilization of autumn and winter water reserves in the soil, so that the first harvest is not dependent on the spring rainfall. If a water deficit occurs, however, the aftermath is small, for the leafy stubble also consumes water (RAIG 1980).

\subsection{Soil}

Goat's rue grows best in light soils, where the stolons can spread out effectively. Soils rich in humus or sandy soils are preferred. The optimum $\mathrm{pH}$ is near neutral, but a $\mathrm{pH}$ range of 5.6-6.0 also allows good yields (RAIG 1980). According to results from Estonia, the Rhizobium bacteria of goat's rue cannot fix nitrogen below pH 5.6 (RAIG 1980). In laboratory conditions in Finland, however, the rhizobia were active at $\mathrm{pH} \mathrm{4,} \mathrm{though} \mathrm{the} \mathrm{plant}$ itself did not thrive in this acidity (LINDSTRÖM et al. 1985).

\section{Establishment of a goat's rue stand}

The procedure in establishing a stand of goat's rue is similar to that for red clover, but goat's rue has some special characteristics that 
should be taken into account. Heavy soils are not suitable and in the seeding year goat's rue develops slowly and is susceptible to shading from other plants. For effective nitrogen fixation, it is also absolutely necessary to inoculate the seed.

\subsection{Manuring and biological nitrogen fixation}

High dry matter yields of goat's rue take up large amounts of potassium, phosphorus and calcium; a dry matter yield of $10 \mathrm{t} / \mathrm{ha}$ contains $290 \mathrm{~kg}$ potassium, $44 \mathrm{~kg}$ phosphorus, and $180 \mathrm{~kg}$ calcium (RAIG 1982). In acid soils, liming may improve the availability of nutrients. Farmyard manure can be used, but nitrogen fertiliser is recommended (RAIG 1980, 1982). Applications of small amounts of lime ( $1-2$ tons/ha) just before sowing have promoted germination and development of nitrogen fixation (RAIG 1980). The nodules on goat's rue do not develop until the end of the seeding year, but when active they make it self-sufficient with regard to nitrogen. A goat's rue sward inoculated with an effective Rhizobium strain needs an annual fertiliser application of $40 \mathrm{~kg} \mathrm{P} / \mathrm{ha}$ and $100 \mathrm{~kg} \mathrm{~K} / \mathrm{ha}$ (RAIG 1980).

At the Department of Microbiology of the University of Helsinki in 1983-1984, the influence of environmental conditions on the Rhizobium bacteria and the nitrogen fixation of goat's rue were investigated. According to the measurements of nitrogenase activity, the nitrogen fixation of goat's rue was equal to that of red clover. In the seeding year, the nitrogen fixation of both test species started at the end of July, but in later years it started in early spring. The nodules were most active in August, after which the nitrogenase activity declined towards the end of the season. Nitrogen fixation generally ceased a little earlier in the autumn in goat's rue than in red clover, the rhizobia of which were active until the beginning of October. In the long term, the nitrogenase activity was positively correlated with the growth rate of the plants; in the short term, the nitrogenase activity reacted strongly to changes in the environmental conditions, including air temperature (LINDSTRÖM 1984).

Rhizobium bacteria are suggested to be sensitive to acid conditions. Experiments performed in Finland to compare nitrogen-fixing goat's rue with plants receiving mineral nitrogen in five different acid soils showed that acidity had the same effect on the yields of the symbiotically grown plants as on the plants receiving mineral nitrogen, which suggests that the sensitivity of the symbiosis to acidity did not limit plant growth even under very acid conditions. It was also concluded that goat's rue, its symbiotic nitrogen fixation and the rhizobia are tolerant of moderately acid agricultural soils. Severe winters may reduce bacterial numbers in the soil, because the nodules are sensitive to low temperatures $\left(-5^{\circ} \mathrm{C}\right)$ (LindSTRÖm et al. 1985).

\subsection{Seed preparation}

Half of the total seed yield of goat's rue can consist of hard seeds, whose germination can be improved by acid treatment or mechanical scarifying. In Estonia the seeds were soaked in concentrated nitric acid for $1-2$ hours to soften the coats (RAIG 1980). In Helsinki, seeds have been scarified mechanically.

The germination of goat's rue seeds varies in different years. Seed produced in Finland has had fairly high germination; for example, in 1982 after the mechanical treatment it was $82+4 \%$.

The Rhizobium species infecting goat's rue does not occur in Finnish soils and inoculation with the appropriate rhizobia is thus essential for successful cultivation. Orginally, Estonian strains were used, but the Department of Microbiology has now undertaken to provide an effective domestic Rhizobium strain for goat's rue.

\subsection{Sowing}

\subsubsection{Sowing time and depth}

It is recommended that a goat's rue sward 
be established early in the spring, when the seedlings can utilize the spring moisture in the soil. When sown early, the plants also have time to become sturdy before the winter. In Estonia the best results have been obtained from seedings during the first two weeks in May but in cold springs sowing must be delayed until the beginning of June. This can reduce yields in the first two years. Seeding in June-August is not recommended in Estonia (RAIG 1980).

In most soils a sowing depth of $1.0-1.5 \mathrm{~cm}$ is usually sufficient, but it is generally best to sow $1 \mathrm{~cm}$ deeper, to assure proper germination. Early growth is suppressed when seed is sown deeper than $2.5-3.0 \mathrm{~cm}$ (RAIG 1980).

\subsubsection{Seeding rate}

The utilization of the ley determines the sowing rate. In Estonia a row spacing of $20-30 \mathrm{~cm}$ and a seeding rate of $30-40 \mathrm{~kg} / \mathrm{ha}$ are recommended for a sward for fodder. For seed production, a wider row spacing (60$90 \mathrm{~cm})$ and a lower seeding rate $(7-10 \mathrm{~kg} / \mathrm{ha})$ are recommended (RAIG 1980).

In Finnish field trials, a seeding rate of $40 \mathrm{~kg} / \mathrm{ha}$ has been shown to give the maximum yields. However, in our conditions a row spacing of $12-14 \mathrm{~cm}$ seems to be better than wider ones. The effect of the seeding rate was evident in the two first years; later, the environmental conditions and management practices become more important (KANSANEN 1983, MäKÄräInen et al. 1985) (Fig. 1).

\subsection{Cover crop}

During the sowing year the development of goat's rue is very slow, the yield is small and the stand is easily overgrown by weeds. To increase the yield in the establishing year and to suppress the weeds, a cover crop seemed to be necessary.

At the Department of Plant Husbandry two series of trials were carried out to test various cover and companion crops for goat's rue. In the first trial series in 1978-79, the highest dry matter yields in the seeding year were obtained from a sward where Italian ryegrass was used as a cover crop (Table 1). The lowest yields were obtained from the plots without a cover crop or with timothy as a companion crop. In the next summer, plots with red clover grew best and produced the highest yields. Barley as a cover crop was most detrimental. Unfortunately, the trial field was badly damaged by an ice cover during winter 1979-80.

In the second trial 1979-80, five cover/ companion crops were compared. (Fig. 2).

In the sowing year, the plots sown with red
Fig. 1. Effect of the seeding rate on the total DM yield from goat's rue swards in successive years (establishment year excluded), 1980-1983 (МӒ. . RÄINEN et al. 1985).

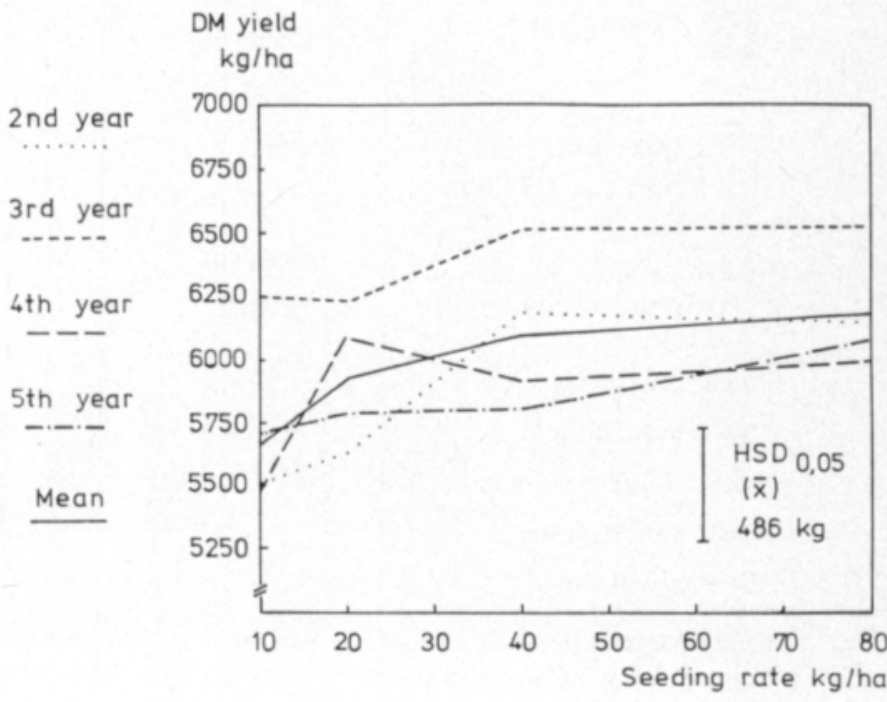


Table 1. Effect of various cover and companion crops on the DM yields of a goat's rue sward. Averages for different densities of cover/companion crops. Seeding year 1978, 1st year sward 1979; $75 \mathrm{~kg} / \mathrm{ha} \mathrm{N}$ applied every spring. Two cuts per year (except for red clover, barley and sward without cover crop in sowing year) (MÃKĀRĀINEN et al. 1985).

\begin{tabular}{lllr}
\hline \multirow{2}{*}{$\begin{array}{l}\text { Cover/companion } \\
\text { crops }\end{array}$} & \multicolumn{3}{c}{ DM yields kg/ha } \\
\cline { 2 - 4 } & \multicolumn{1}{c}{1978} & 1979 & Total \\
\hline T. resupinatum & $3280 \mathrm{~b}$ & $4180 \mathrm{a}$ & 7460 \\
$T$. pratense & $3480 \mathrm{~b}$ & $6680 \mathrm{c}$ & 10160 \\
L. multiflorum & $4580 \mathrm{c}$ & $5720 \mathrm{~b}$ & 10300 \\
$H$. vulgare & not & & \\
G. orientalis alone & available & $3490 \mathrm{a}$ & - \\
\hline
\end{tabular}

clover produced most and the plots without a companion crop and those with timothy least. In the next year the timothy grew as well as the red clover, but the highest total yields were obtained from the plots sown with red clover. Italian ryegrass and Persian clover suppressed the growth of goat's rue too much, leaving behind a very poor stand.

In the sowing year all cover/companion crops impaired the development of goat's rue and the harvested yield consisted mostly of the cover/companion crop. The goat's rue was suppressed most strongly by annual crops, such as barley, Persian clover and Italian ryegrass. The ryegrass survived winter $1978-79$ and this exceptional overwintering is the reason for the favourable results obtained with it in the first trial series. The trials were too short to establish definitely which of the cover/ companion crops is the most suitable, but from the experience gathered we can conclude that in the long term the best way to establish a pure goat's rue sward is to sow it without a cover/companion crop. If necessary, weeds can be controlled with herbicides, and in this way a productive, long-lasting sward can be established.

\subsection{Goat's rue - timothy mixtures}

Being a legume, goat's rue contains more protein and less sugar than grasses. Its low sugar content complicates the use of a preservative in silage making and impairs the palatability of the silage. To improve the quality of the silage, trials were carried out in which goat's rue was grown as a mixture with grasses. The mixture also competes better with weeds in the sowing year. According to Estonian studies, mixed stands produce more than pure goat's rue stands, especially in acid soils. Timothy, orchard grass (Dactylis glomerata) and meadow foxtail (Alopecurus

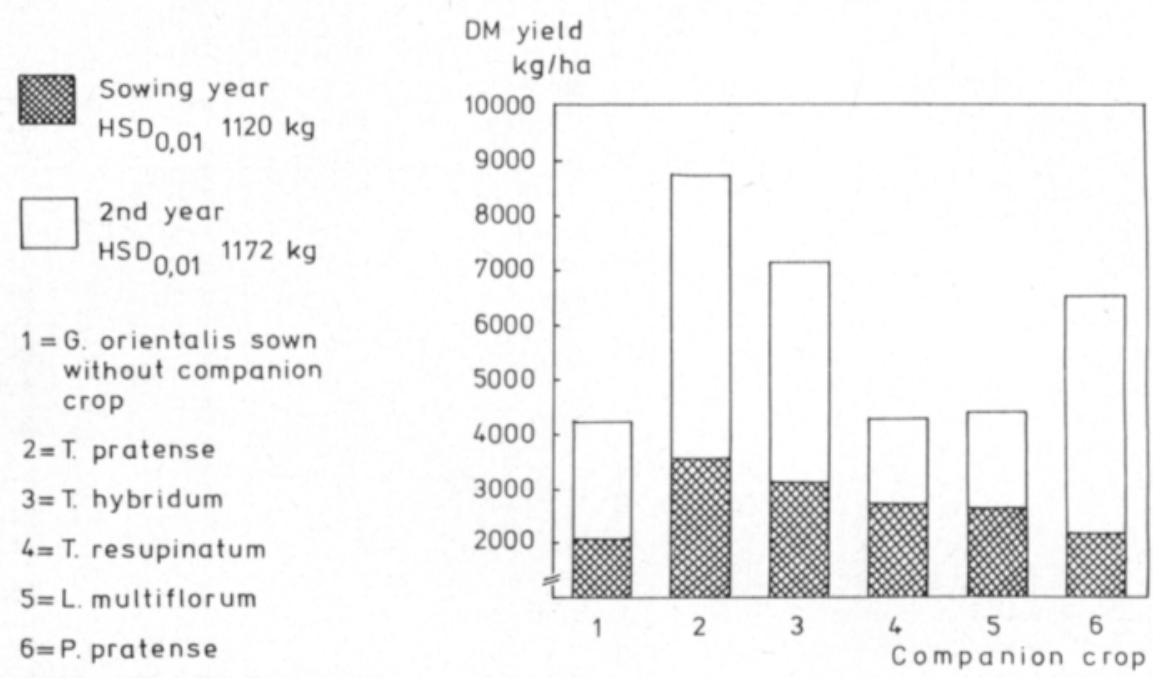

Fig. 2. Total DM yields from the sowing-and 1st-year sward of goat's rue established with various cover/companion crops. Trials from years 1979-80. No nitrogen was applied (MÄKÄRÃINEN et al. 1985). 
tenuis) have proved suitable for mixing with goat's rue (RAIG 1982).

In Finnish trials in 1981-1984, goats rue - timothy mixtures were studied applying a 2-cut system (KANSANEN 1983, MÄKÄRÄINEN et al. 1985) (Table 2).

Without added nitrogen, mixtures of timothy and goat's rue gave higher dry matter yields than pure stands of goat's rue or timothy. Nitrogen application encouraged the growth of timothy and weeds. The composition of the mixtures changed as the sward aged. In the beginning, the proportion of timothy in the yield was higher than expected from the seed mixture. In the 3rd and 4th year, the proportion of goat's rue started to increase. The proportion of weeds was $12 \%$ in the sowing year and lower in the second year, but started to increase when timothy became sparse, especially in plots where nitrogen was applied.

The higher the proportion of goat's rue in the mixture, the higher were most of the crude protein yields. In the last year the crude protein yield was highest in sward with $60 \%$ goat's rue in the mixture. This mixture also produced the highest dry matter yields. Nitrogen application improved the crude protein yields significantly only in the two first years and the improvement was greatest in pure timothy stands.

The crude protein contents of the yield increased as the proportion of goat's rue in the mixture increased. Nitrogen application raised the protein content significantly only in the first cuts in 1981 and 1984 (Table 3). In general, the crude protein content was slightly higher in the first cut than in the second.

Table 2. Total DM and CP yields from mixed stands of goat's rue and timothy in 1981-84 (MÃKÃRÃINEN et al. 1985).

\begin{tabular}{|c|c|c|c|c|c|c|c|c|c|c|}
\hline \multicolumn{2}{|c|}{$\begin{array}{l}\text { Mixture } \\
\text { G. orientalis }\end{array}$} & \multicolumn{3}{|c|}{ P. pratense } & \multicolumn{3}{|c|}{$\begin{array}{c}\text { DM } \\
\mathrm{kg} \mathrm{N} / \mathrm{ha}\end{array}$} & \multicolumn{3}{|c|}{$\begin{array}{c}\mathrm{CP} \\
\mathrm{kg} \mathrm{N} / \mathrm{ha}\end{array}$} \\
\hline$\%$ & $\mathrm{~kg} / \mathrm{ha}$ & . & $\%$ & $\mathrm{~kg} / \mathrm{ha}$ & & 0 & 120 & & 0 & 120 \\
\hline 100 & 30 & & - & - & & $25680 \mathrm{bc}$ & $23543 \mathrm{a}$ & & $4638 d$ & $4454 b$ \\
\hline 80 & 24 & & 20 & 2 & & $26244 \mathrm{bc}$ & 26 792ab & & $4089 c$ & $4434 b$ \\
\hline 60 & 18 & & 40 & 4 & & $27619 \mathrm{c}$ & $27057 \mathrm{ab}$ & & 4 291cd & $4310 \mathrm{~b}$ \\
\hline 40 & 12 & & 60 & 6 & & $24561 b c$ & $29296 \mathrm{~b}$ & & $3775 c$ & $4088 \mathrm{~b}$ \\
\hline 20 & 6 & & 80 & 8 & & $22797 \mathrm{bc}$ & $24378 \mathrm{ab}$ & & $3093 b$ & $3193 a$ \\
\hline- & - & & 100 & 10 & & $16379 a$ & $25205 \mathrm{ab}$ & & $1521 \mathrm{a}$ & $2969 a$ \\
\hline \multirow[t]{2}{*}{ Mean } & & & & & & 23880 & 26045 & & 3568 & 3908 \\
\hline & & & & & $\mathrm{N}$ & Mix & $\mathrm{N} \times \mathrm{Mix}$ & $\mathrm{N}$ & Mix & $\mathrm{N} \times$ Mix \\
\hline F-value & & & & & ns & $* * *$ & ** & ns & $* * *$ & $* * *$ \\
\hline $\mathrm{HSD}_{0.05}$ & & & & & - & $3577 \mathrm{~kg}$ & $5058 \mathrm{~kg}$ & - & $479 \mathrm{~kg}$ & $677 \mathrm{~kg}$ \\
\hline
\end{tabular}

Table 3. Crude protein contents from mixtleres of goat's rue and timothy in 1981-84 (MÃKÄRÃNEN et al. 1985).

\begin{tabular}{|c|c|c|c|c|c|c|c|}
\hline \multirow{2}{*}{$\begin{array}{l}\text { Mixture } \\
\text { G. orientalis } \\
\\
\%\end{array}$} & \multirow[t]{2}{*}{$\begin{array}{c}P . \text { pratense } \\
\%\end{array}$} & \multicolumn{2}{|c|}{$\begin{array}{c}1982 \\
\mathrm{~kg} \mathrm{~N} / \mathrm{ha}\end{array}$} & \multicolumn{2}{|c|}{$\begin{array}{c}1983 \\
\mathrm{~kg} \mathrm{~N} / \mathrm{ha}\end{array}$} & \multicolumn{2}{|c|}{$\begin{array}{c}1984 \\
\mathrm{~kg} \mathrm{~N} / \mathrm{ha}\end{array}$} \\
\hline & & 0 & 120 & 0 & 120 & 0 & 120 \\
\hline 100 & 0 & 19.8 & 19.7 & 19.8 & 21.5 & 15.5 & 16.6 \\
\hline 80 & 20 & 15.0 & 16.8 & 16.8 & 19.0 & 14.4 & 14.2 \\
\hline 60 & 40 & 12.8 & 14.8 & 17.0 & 18.7 & 14.3 & 13.8 \\
\hline 40 & 60 & 13.9 & 13.0 & 16.1 & 18.0 & 14.5 & 11.7 \\
\hline 20 & 80 & 11.8 & 12.1 & 13.6 & 16.1 & 13.6 & 11.8 \\
\hline 0 & 100 & 10.8 & 11.9 & 9.6 & 14.9 & 8.3 & 8.6 \\
\hline Average & & 14.0 & 14.7 & 15.5 & 18.0 & 13.4 & 12.8 \\
\hline
\end{tabular}




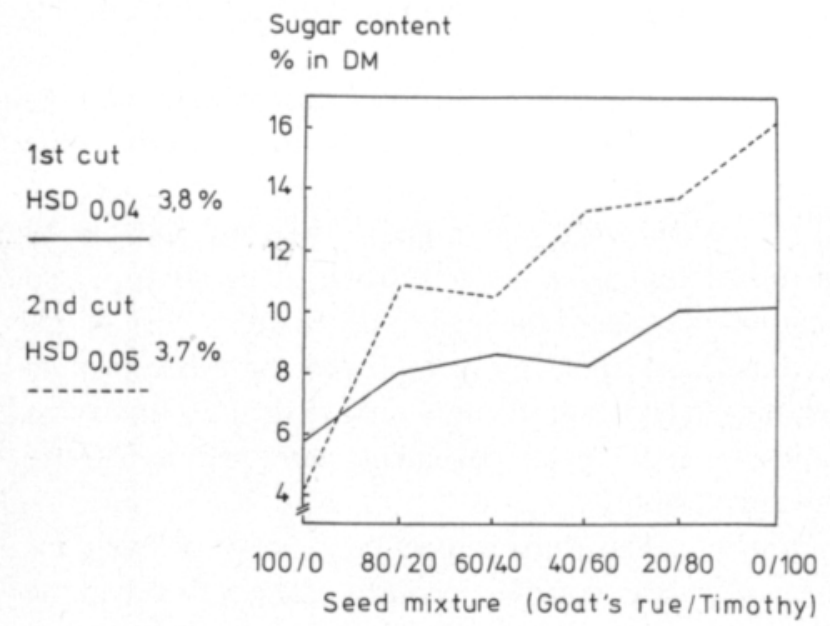

Fig. 3. Sugar contents of mixtures of goat's rue and timothy in $1981-84$ (МАK $\AA$ RÄINEN et al. 1985).
The crude fibre contents did not correlate with the proportion of goat's rue in the mixture as clearly as did the protein contents. Usually pure goat's rue stands, or stands in which goat's rue predominated contained most crude fibre. Nitrogen application had no effect on the crude fibre content (Table 4).

The sugar contents of the yields depended on the proportion of timothy in the mixture, improving significantly when it increased (Fig. 3). Nitrogen application had no effect on the sugar content of the yields.

It can be concluded that a mixture of goat's rue and timothy in which the proportion of goat's rue is more than half can produce high dry matter yields even without nitrogen applications. In the first two years applied nitrogen may have a positive effect, but in later years the proportion of goat's rue increases and nitrogen applications are not required. The composition of the mixture affects the quality of the yield more than the quantity. When the proportion of timothy in the mixture increases, the crude protein content decreases and the sugar content increases, in spite of nitrogen applications. The composition of the mixture has no pronounced effect on the crude fibre content.

\section{Cutting times}

\subsection{Number of cuttings}

Only one cut of $G$. orientalis is possible in the seeding year, but in subsequent years two or three cuts are possible. In Estonia, higher protein and dry matter yields were obtained with three cuts (RAIG 1980), but two cuttings were better for overwintering (JARTIJEVA 1977). Cutting three times may disturb the

Table 4. Crude fibre contents of mixtures of goat's rue and timothy in 1981-84 (MÃKĀÄINEN et al. 1985)

\begin{tabular}{|c|c|c|c|c|c|c|c|}
\hline \multirow{2}{*}{$\begin{array}{l}\text { Mixture } \\
\text { G. orientalis }\end{array}$} & \multirow{2}{*}{$\begin{array}{l}\text { P. pra- } \\
\text { tense }\end{array}$} & \multicolumn{2}{|c|}{1982} & \multicolumn{2}{|c|}{1983} & \multicolumn{2}{|c|}{1984} \\
\hline & & 1st cut & 2nd cut & 1st cut & 2 nd cut & 1st cut & 2nd cut \\
\hline 100 & 0 & 24.0 & 29.9 & 31.2 & 25.6 & 29.4 & 32.3 \\
\hline 80 & 20 & 27.8 & 27.6 & 29.3 & 26.1 & 27.4 & 30.1 \\
\hline 60 & 40 & 27.4 & 27.4 & 27.7 & 24.6 & 27.3 & 33.0 \\
\hline 40 & 60 & 27.8 & 26.6 & 28.4 & 23.0 & 27.6 & 30.7 \\
\hline 20 & 80 & 27.8 & 25.9 & 29.3 & 22.0 & 27.0 & 30.9 \\
\hline 0 & 100 & 28.4 & 26.3 & 29.0 & 26.1 & 26.2 & 26.5 \\
\hline Average & & 27.2 & 27.3 & 29.2 & 24.6 & 27.5 & 30.6 \\
\hline
\end{tabular}


stolon growth and the storage of carbohydrates (RaIG 1982). In the preliminary trials at the Department of Plant Husbandry in 1978-79, two cuts were found be more appropriate for Finnish conditions (KANSANEN 1983) and the 2-cut system was applied in all the trials reported here.

\subsection{Time of first cutting}

The dry matter yield of goat's rue increases until the full flowering stage, but the quality of the yield is better when it is harvested before flowering (RAIG 1982). The time between the first and second cutting should be long enough for formation of the stolons, so that delay of the first cutting can hazard the overwintering and the first cut yield in the following year (RAIG 1980).

In 1980 a three-year trial was established at the Department of Plant Husbandry to investigate the effects of the times of first cutting on the yields of goat's rue (KanSANEN 1983, MÄKÄräinen et al. 1985 (Table 5).

The after-effect of the cutting schedule is seen only in 1982. There are some indications that when the first harvest takes place early (16.6.), at the beginning of flowering, in the previous years, the sward produces best in the long term. The results of root analyses also indicate that, for proper development of stolons, 70 days is a suitable interval between cuttings.

\subsection{Time of second cutting}

The date of the autumn cutting affects overwintering and also the yield and its quality, as goat's rue keeps growing until late autumn. Cutting too early encourages the growth of the stolon buds and increases winter damage; regrowth after cutting also consumes the carbohydrate reserves of the plant. In Estonia, postponing the autumn cutting from the middle of September to the middle of October increased the yields in both that and the following year. The most unfavourable cutting time was the end of August, which is the time recommended for red clover (RAIG 1982).

Two series of trials were carried out at the Department of Plant Husbandry to investigate the effects of autumn cutting times on the yields of goat's rue. The results from the first series, in 1979-1983, are given in Figure 4.

In the seeding year, the treatment 20.8./ $5 \mathrm{~cm}$ was not harvested, which is probably why it yielded exceptionally well in 1980 . In later years, the late autumn harvest was regularly better than the earlier one. The stubble height had no clear effect on the yields.

Some results of a second trial series incorporating five autumn cutting times in 1981-83 are given in Table 6 and Figure 5.

The results obtained are similar to those from Estonia in that the following year's yield was greater if the stand was cut late in the previous autumn. Overwintering was also im-

Table 5. Effect of the date of 1st cutting on the DM yield from goat's rue leys in 1980-1982 (MĀKÄRÃINEN et al. 1985).

\begin{tabular}{|c|c|c|c|c|c|c|c|c|}
\hline \multirow{3}{*}{$\begin{array}{l}\text { Time } \\
\text { of the } \\
\text { lst cut }\end{array}$} & \multirow{3}{*}{$\begin{array}{l}\text { Time } \\
\text { between } \\
\text { 1st and } \\
\text { 2nd cut }\end{array}$} & \multicolumn{7}{|c|}{ Total DM yield } \\
\hline & & \multicolumn{2}{|c|}{$1980^{1}$} & \multicolumn{2}{|c|}{$1981^{2}$} & \multicolumn{2}{|c|}{$1982^{3}$} & \multirow{2}{*}{$\begin{array}{c}1980-82 \\
\mathrm{~kg} / \mathrm{ha}\end{array}$} \\
\hline & & $\mathrm{kg} / \mathrm{ha}$ & $\%$ & $\mathrm{~kg} / \mathrm{ha}$ & $\%$ & $\mathrm{~kg} / \mathrm{ha}$ & $\%$ & \\
\hline 5. 6 . & 83 & 3010 & 103 & 5910 & 83 & 4540 & 90 & 13470 \\
\hline 16. 6. & 72 & 2720 & 93 & 5750 & 81 & 6070 & 120 & 14540 \\
\hline 26. 6. & 60 & 3040 & 104 & 7770 & 109 & 4880 & 96 & 15680 \\
\hline 8. 7. & 50 & 2890 & 99 & 9120 & 128 & 4760 & 94 & 16770 \\
\hline$x$ & & 2920 & $=100$ & 7140 & $=100$ & 5060 & $=100$ & 15120 \\
\hline
\end{tabular}

1 Cut only on 5. 9.

2 The 2 nd cut on 29.8 .

3 The 2 nd cut on 15.9 . 


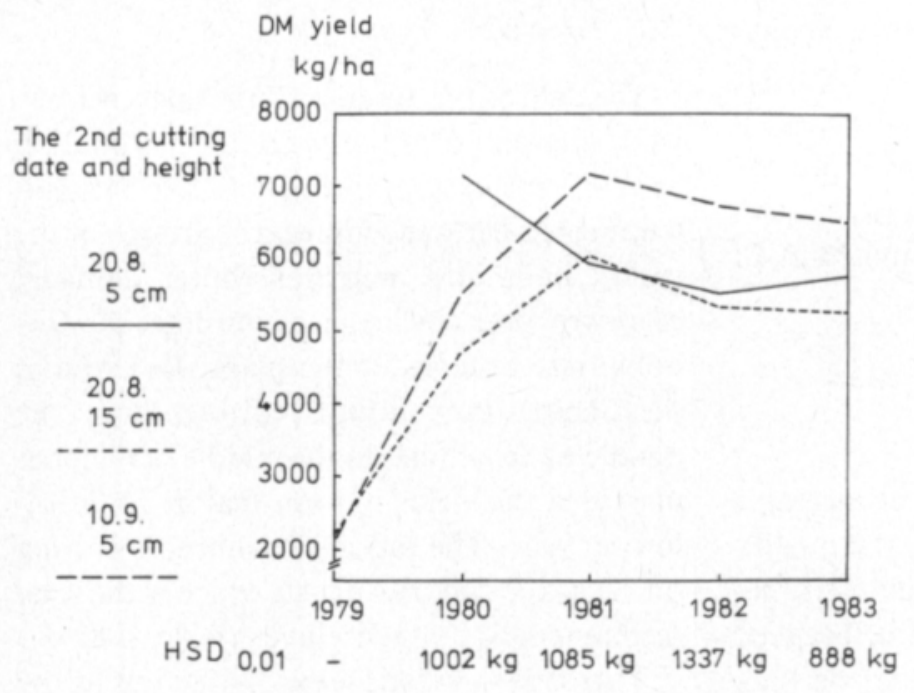

Crude protein content $\%$ in DM

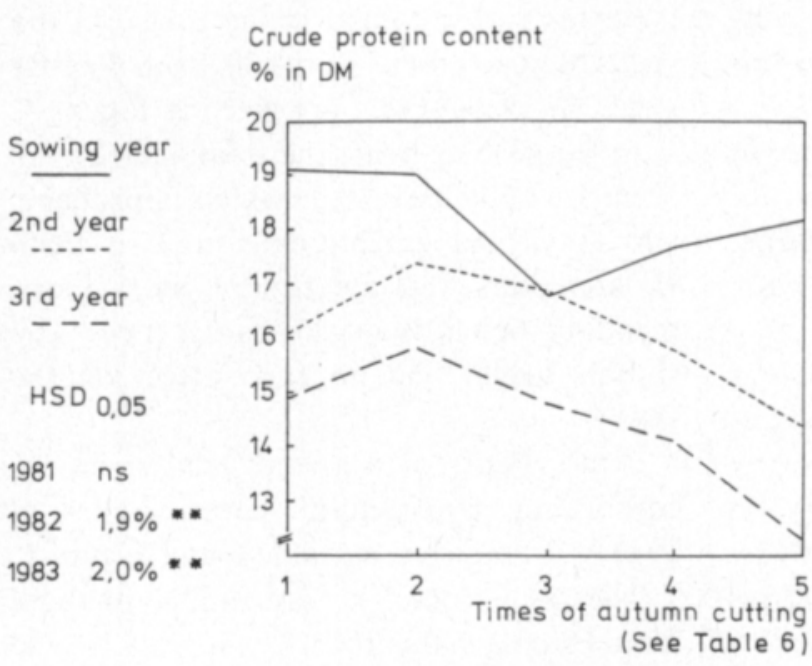

Fig. 4. Effect of the date and height of 2 nd cutting on the DM yield from 2 to 5-year-old goat's rue swards (MÃKÄrÄINEN et al. 1985).
Fig. 5. Crude protein content ( $\%$ DM) of goat's rue leys in autumn 1981-1983 (MÁkÄräinen et al. 1985).
Table 6. Effect of the date of 2nd cutting on the DM and CP yield $(\mathrm{kg} / \mathrm{ha})$ from goat's rue leys in 198! - 1983 (MÄKÄRĀINEN et al. 1985).

\begin{tabular}{lrrrlll}
\hline \multicolumn{3}{c}{ Cutting time in autumn } & & DM & CP \\
\cline { 1 - 2 } & 1981 & 1982 & 1983 & & Total & Total \\
\hline 1 & 18.8. & 16.8. & 18.8. & & $17564 \mathrm{ab}$ & $3131 \mathrm{ab}$ \\
2 & 26.8. & 31.8. & 29.8. & & $15764 \mathrm{a}$ & $2950 \mathrm{ab}$ \\
3 & 7.9. & 9.9. & 9.9. & $16271 \mathrm{ab}$ & $2860 \mathrm{a}$ \\
4 & 22.9. & 23.9. & 27.9. & $19634 \mathrm{~b}$ & $3484 \mathrm{~b}$ \\
5 & 5.10. & 5.10. & 3.10. & $19150 \mathrm{ab}$ & $3365 \mathrm{ab}$ \\
\hline $\bar{x}$ & & & & 17677 & 3157 \\
F-value & & & $*$ & $*$ \\
HSD & & & $3668 \mathrm{~kg}$ & $591 \mathrm{~kg}$ \\
\hline
\end{tabular}

proved and more stolons were formed. The quality of the autumn yield decreased with delayed cutting time, and, as expected, the protein content was lower and the crude fibre content higher.

In Finnish conditions, the least suitable time for the second cut seems to be the end of August, and a favourable time seems to be the second half of September.

\subsection{Combinations of cutting times}

In 1983, a series of trials was established 
Table 7. Total DM yield $(\mathrm{kg} / \mathrm{ha})$ from goat's rue leys in 1983-85.

\begin{tabular}{crrrrr}
\hline Cutting time & \multicolumn{5}{c}{ Cutting time in the summer } \\
in the autumn & 4.6. & 11.6. & 19.6. & 28.6. \\
\hline 24.8. & 8275 & 10271 & 9187 & 9961 & $9423 \mathrm{a}$ \\
7.9. & 12268 & 13191 & 13235 & 13298 & $12998 \mathrm{c}$ \\
16.9. & 10741 & 12421 & 12883 & 13303 & $12337 \mathrm{c}$ \\
5.10. & 10332 & 11595 & 11861 & 12414 & $11551 \mathrm{~b}$ \\
\hline $\mathrm{x}$ & 10404 & 11869 & 11792 & 12244 & $11577 \mathrm{~b}$ \\
\hline F-value & Autumn cut & $* * *$ & HSD $_{0.05}$ & & 718 \\
\hline
\end{tabular}

Table 8 . Total crude protein yield $(\mathrm{kg} / \mathrm{ha})$ from goat's rue leys in 1983-85.

\begin{tabular}{cccccc}
\hline Cutting time & \multicolumn{4}{c}{ Cutting time in the summer } \\
in the autumn & 4.6. & 11.6. & 19.6. & \multicolumn{1}{c}{28.6.} \\
\hline 24.8. & 2557 & 3297 & 2777 & 3051 & 2921 \\
7.9. & 3511 & 3821 & 3998 & 4176 & 3876 \\
26.9. & 3155 & 3838 & 3623 & 4116 & 3683 \\
3.10. & 2966 & 3677 & 3514 & 3690 & 3462 \\
\hline$x$ & 3047 & 3658 & 3478 & 3758 \\
\hline
\end{tabular}

with different combinations of 1 st and 2 nd cutting times. The results are presented in Tables 7 and 8 .

The total dry matter yields seem to be best when the first cutting was done before full flowering, in the second half of June, and the second cutting in mid September. With these dates the quality of the yields is also good. The earliest cutting times proved to be unsuitable both in summer and in autumn. The effect of the cutting date on the quality of the yields was similar to that in other experiments: the fibre content was higher and the protein content lower when the crop was cut late.

\section{Yield}

\subsection{Quantity of yield}

In the seeding year, the development of the overground parts of goat's rue is slow and cutting can be done in late autumn only. At this time the sward is about $40-60 \mathrm{~cm}$ high. The yield of goat's rue in the seeding year is significantly smaller than that of red clover grown under the same conditions.
The root system of goat's rue grows vigorously in the sowing year and in the autumn, the dry matter yield of the roots may be threefold the dry weight of the tops. Goat's rue does not flower in the seeding year unless sown very early. The seed yield of the sowing year, if any, consists mainly of hard seed (RAIG 1980).

In the second year, the growth of goat's rue, partly from stolon buds, begins much faster than in the sowing year. The growth rhythm is about two weeks earlier than in red clover. In Estonia, goat's rue swards have proved to be very permanent, being highly productive for $7-15$ years. In good conditions the yields have been as high as 13 tons per hectare (RAIG 1982).

In our five-year experiment at the University of Helsinki the yield was highest in the third year (Fig. 6).

The yield level of $6000-7000 \mathrm{~kg}$ DM per hectare was not so high as that recorded in Estonia. In a variety trial at the Sata-Häme research station $200 \mathrm{~km}$ north of Helsinki, the yield from a 1st-year goat's rue ley in 1984 was $6420 \mathrm{~kg}$ DM per ha, or 67 per cent of the yield 


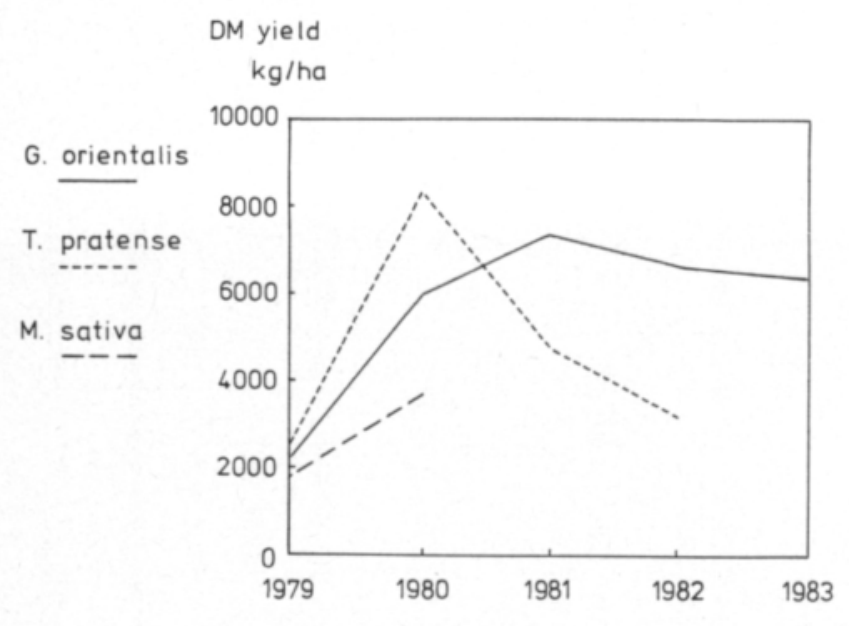

Fig. 6. DM yields of goat's rue, red clover and lucerne at the Department of Plant Husbandry, Helsinki, Finland in 1979-1983 (MĀKÄrĀINEN et al. 1985).

of the best red clover variety, Venla (МÃKÄRÄINEN et al. 1985). The same was true in University trials but, in later years, the yield from goat's rue clearly exceeded that of the other legumes tested, because red clover and lucerne did not overwinter properly.

\subsection{Quality of yield}

\subsubsection{Chemical composition}

The chemical composition of goat's rue is similar to that of other perennial legumes such as red clover and lucerne (Table 9).

At the University of Helsinki, some of the quality characteristics were measured in 1981 and 1982 (Fig. 7).

The crude protein content in goat's rue was somewhat higher than in red clover at the same development stage. The protein content also decreased more slowly in goat's rue, but goat's rue had a higher crude fibre content than red clover.

The differences in quality between the summer and autumn yields varied, depending on the cutting schedule. The differences may be quite small (Table 10), but the percentage of crude fibre may be high in a late autumn cutting.

Sixteen amino acids have been isolated from goat's rue. According to JARTIJEVA (1977), the amount of amino acids in the dry matter decreases with developing senescence, but their proportions remain unchanged. No reliable comparisons have been made between the amino acid contents of goat's rue and other legumes.

According to our results, goat's rue contained significantly less potassium, calcium and magnesium than red clover. The phosphorus content was about the same in the two species (Table 11).

Table 9. Prebloom composition (\% DM) of G. orientalis, G. officinalis, $T$. pratense and M. sativa (MAKKÃÃINEN et al. 1985).

\begin{tabular}{lcccc}
\hline & $\begin{array}{c}\text { G. orien } \\
\text { talis }^{1}\end{array}$ & $\begin{array}{c}\text { G. offici- } \\
\text { nalis }^{2}\end{array}$ & $\begin{array}{c}\text { T. pra- } \\
\text { tense }^{3}\end{array}$ & M. sativa $^{3}$ \\
\hline Dry matter & 27.0 & 17.0 & 15.0 & 21.0 \\
Ash & 9.5 & 7.7 & 10.0 & 10.0 \\
Crude protein & 18.9 & 20.0 & 18.0 & 21.0 \\
Fat & 2.7 & 3.2 & 4.0 & 3.0 \\
Crude fibre & 23.0 & 29.8 & 22.0 & 25.0 \\
Crude carbohydrates & 41.2 & 30.0 & 46.0 & 41.0 \\
\hline
\end{tabular}

1 Raig 1980, ${ }^{2}$ Regensburger 1954, ${ }^{3}$ Salo et al. 1982. 


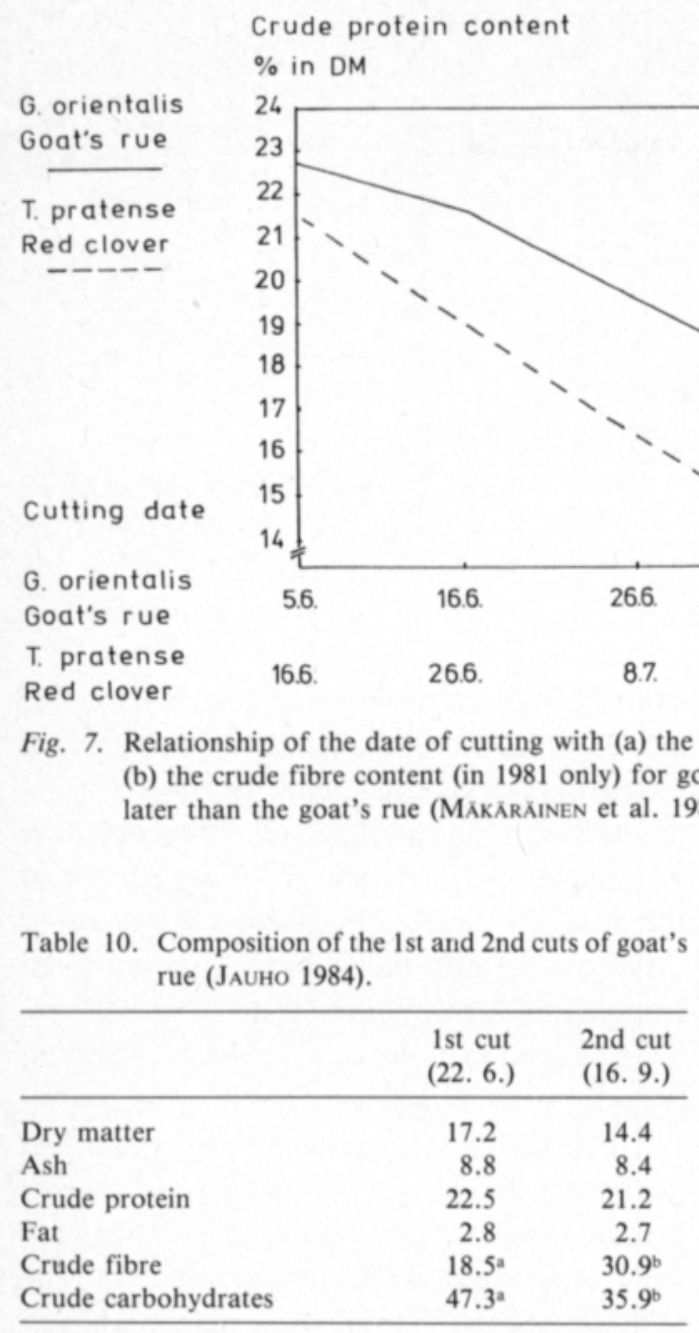

\subsubsection{Digestibility and feeding value}

Goat's rue keeps its feeding value very long, due to continuous development of new shoots. The stand is still green when the seeds of the main crop mature (RAIG 1980).

The stage of development affects the digestibility, as the proportion of indigestible

\section{Crude fibre content \\ $\%$ in DM}

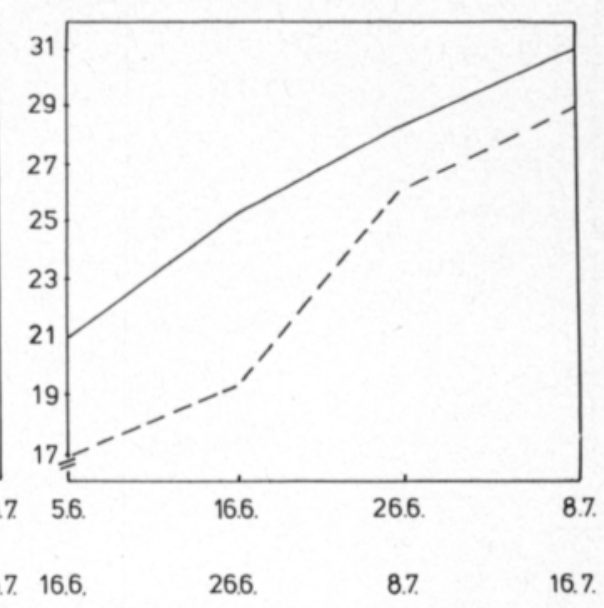

16.7. 16.6

stems and petioles increases with age. In Estonian trials, the ranges of the digestibilities of different components from shooting to full flowering were as follows (RAIG 1980):

$\begin{array}{ll}\text { Dry matter } & 66.7-53.3 \% \\ \text { Carbohydrates } & 77.8-56.0 \% \\ \text { Crude protein } & 85.9-63.0 \% \\ \text { Fat } & 53.0-33.0 \% \\ \text { Crude fibre } & 68.6-44.9 \% \\ \text { Crude carbohydrates } & 83.7-60.7 \%\end{array}$

\subsubsection{Alkaloids}

The feeding value of goat's rue is impaired by alkaloids. Three different alkaloid compounds have been isolated from goat's rue: the guanidine derivatives galegine and 4-hydroxygalegine, and the chiazoline-type (+)-peganine (SCHreiber et al. 1962) (Fig. 8).

Table 11. Mineral contents (\% DM) of goat's rue and red clover (Venla) yields at different dates in 1981 (MÃK. RÄINEN et al. 1985).

\begin{tabular}{|c|c|c|c|c|c|c|c|c|}
\hline \multirow{2}{*}{$\begin{array}{l}\text { 1st cutting } \\
\text { date }\end{array}$} & \multicolumn{4}{|c|}{ G. orientalis $\%$ in DM } & \multicolumn{4}{|c|}{ T. pratense $\%$ in DM } \\
\hline & $\mathbf{P}$ & K & $\mathrm{Ca}$ & $\mathrm{Mg}$ & $\mathrm{P}$ & K & $\mathrm{Ca}$ & $\mathrm{Mg}$ \\
\hline 5. 6. & 0.41 & 3.52 & 0.19 & 0.15 & - & - & - & - \\
\hline 16. 6. & 0.30 & 3.36 & 0.37 & 0.16 & 0.36 & 3.90 & 1.16 & 0.25 \\
\hline 8. 7. & 0.34 & 2.85 & 0.48 & 0.15 & 0.29 & 3.71 & 0.85 & 0.20 \\
\hline 17. 7. & - & - & - & - & 0.26 & 3.42 & 0.76 & 0.19 \\
\hline
\end{tabular}




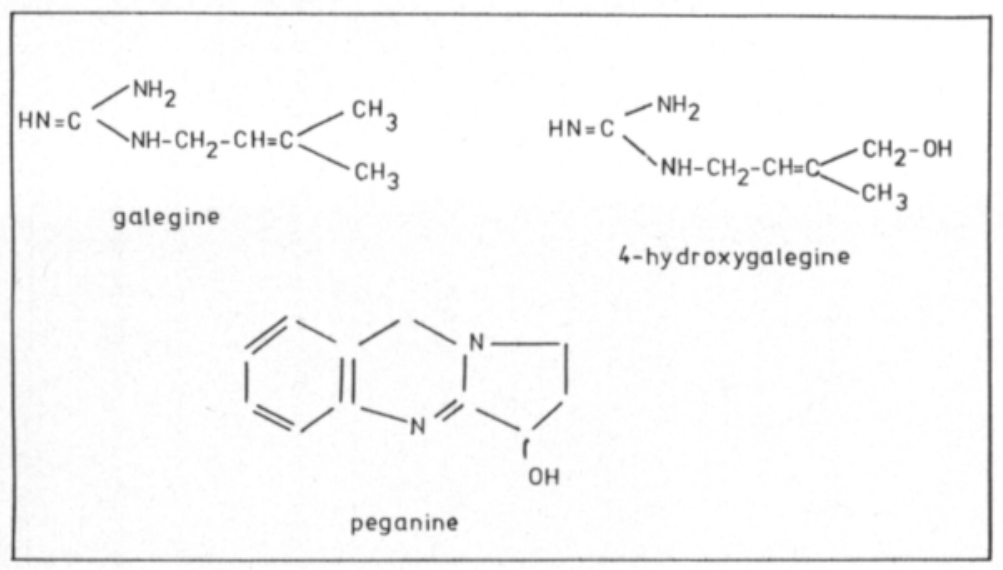

Fig. 8. Alkaloids in goat's rue (SChreiber et al. 1962).

Guanidine derivatives are poisonous in substantial amounts, and even when not poisonous, peganine causes a bitter taste. In the leaves of $G$. officinalis the contents of galegine and 4-hydroxy-galegine are $0.10-0.25 \%$ of dry matter and that of peganine is $0.05-$ $0.1 \%$ (Pufahl and Schreiber 1963). The alkaloid content of $G$. orientalis is lower and, according to German results, it does not contain galegine or 4-hydroxy-galegine (SCHREIBER et al. 1962).

There is more variation in the peganine content of different populations of G. officinalis than in the galegine and 4-hydroxy-galegine contents. The development stage affects the galegine and peganine contents differently. The galegine content is highest during flowering and lowest during seed maturation, whereas the peganine content decreases continuously as the plant ages. The age of the leaf affects the content of 4-hydroxy-galegine less than that of galegine, the trend decreasing with ageing of the leaves. Moisture, photoperiodism and temperature have almost no effect on the galegine content and their effect on other alkaloids is also small (SCHÄFER and STEIN 1969). Similar analyses have not been carried out on $G$. orientalis.

The effects of the alkaloids in G. officinalis and $G$. orientalis on animals were investigated in Germany at the end of the 1960's. It was found that an alcoholic extract from leaves of flowering plants and seeds of $G$. officinalis caused symptoms of poisoning in rats, the leaf extract being more toxic than the seed extract. Small amounts caused depression and greater amounts spasms and paralysis. The lethal dose of galegine sulphate was $77.5 \mathrm{mg}$ per $\mathrm{kg}$ of the animal's weight. Peganine did not cause symptoms of poisoning, but is thought to be responsible for the bitter taste of goat's rue. Seed or seed extracts of $G$. orientalis had no harmful effects (KöHLER 1969).

The possibility of reducing the amount of guanidine derivatives in goat's rue by plant breeding seems to be remote, because they appear to be regulated by several genes and the variation between individual plants is small (RICHTER 1968). The peganine content could be more easily changed by breeding, because there is more variation and more plants with no peganine may be found (SCHÄFER and Stein 1969).

\section{Use as fodder}

\subsection{Silage}

Goat's rue is well suited for both fresh and pre-wilted silage, when growing in pure stands or stands containing $20-25 \%$ grass. As the protein content is high and the sugar content low, successful preservation is secured by using a preservative. According to Estonian results, six litres of preservative per ton of raw material is needed. The use of preservative 
decreases ensiling losses by $35-55 \%$ (RAIG 1980, 1982).

\subsubsection{Goat's rue as silage material}

When the suitability of goat's rue for silage was investigated at the Department of Animal Husbandry of the University of Helsinki in 1982, silage made from goat's rue was found to fulfil the quality requirements set for good silage (Table 12).

Table 12. Characteristics of goat's rue silage in 1982 (JAUHO 1984).

\begin{tabular}{|c|c|c|c|}
\hline Characteristic & $\begin{array}{l}\text { First } \\
\text { cutting }\end{array}$ & $\begin{array}{l}\text { Second } \\
\text { cutting }\end{array}$ & $\begin{array}{c}\text { Recommended } \\
\text { values }\end{array}$ \\
\hline $\mathrm{pH}$ & 3.87 & 3.90 & $3.7-4.0$ \\
\hline \multicolumn{4}{|l|}{$\%$ DM } \\
\hline Lactic acid & 2.69 & 2.17 & $0-1-(2)$ \\
\hline Sugar & 5.26 & 4.44 & more than (1)-2 \\
\hline Acetic acid & 0.87 & 1.17 & no recomm. \\
\hline Propionic acid & 0.04 & + & no recomm. \\
\hline Butyric acid & - & - & less than 0.1 \\
\hline $\mathrm{NH}_{3}-\mathrm{N}$ & 0.07 & 0.16 & below 0.3 \\
\hline Soluble N & 1.53 & 1.35 & no recomm. \\
\hline \multicolumn{4}{|l|}{$\%$ Total N } \\
\hline $\mathrm{NH}_{3}-\mathrm{N}$ & 2.13 & 4.61 & no recomm. \\
\hline Soluble N & 44.9 & 39.6 & no recomm. \\
\hline
\end{tabular}

The $\mathrm{pH}$ of the silages was optimal and the amount of lactic acid was acceptable. The sugar contents were high, especially in the first cut. The ammonium content, the measure of decomposition of $\mathrm{CP}$, was higher in the second cut than in the first cut, but was satisfactory, as was the proportion of soluble nitrogen in total nitrogen. Acetic acid was rather high, but no butyric acid was found.

Storage losses were higher in the first-cut silage (Table 13).

Table 13. Storage losses of goat's rue silages (JAUно 1984).

\begin{tabular}{lcc}
\hline & 1st yield & 2nd yield \\
\hline Effluent, \% FWT & 18.3 & 19.5 \\
Effluent \% DM & 5.2 & 4.7 \\
Fermentation \% DM & 2.0 & 1.5 \\
Putrefaction \% DM & 12.1 & 0.4 \\
Total DM loss & 19.3 & 6.6 \\
\hline
\end{tabular}

In silage making, most putrefaction losses usually take place in summer because of the high temperature. Usually, only soluble components, such as minerals and sugars, are lost in the effluent, but goat's rue effluent also contained much protein (more than $25 \%$ of effluent DM). The fermentation losses in the first cutting were due to crude protein $(6.2 \%)$ and crude carbohydrates $(7.0 \%)$. The major part of the fermentation losses in autumn were due to losses of crude carbohydrates. Putrefaction losses affected all components of the silage alike. Total losses were greatest in the proteins in both silages. From the first cutting, $23.6 \%$ of the crude protein was lost, and from the second cutting $4.8 \%$.

\subsubsection{Digestibility and feeding value of goat's rue silage}

The feeding value of goat's rue silage was investigated at the Department of Animal Husbandry in 1983 in vitro and in vivo (JAUно 1984). Four Texel rams were fed with silage made from the first and second cuttings of goat's rue. The silage was made with "AIV II"' preservative. The fodder rations were calculated to be equivalent to the maintenance requirement of the rams. In addition the animals were given minerals.

The raw material from the second cutting was older and the silage less digestible (Table 14). The in vitro digestibility of the organic matter in the raw material of the first cut was $75.8 \%$ and in the second cut $64.5 \%$. Silage making reduced the digestibility of the organic matter in the first-cut silage to $72.6 \%$ and in the second-cut to $57.7 \%$. The in vivo digestibility was measured on the silage alone. All components of the silage were significantly more digestible in the first cutting than in the second. The fibre content and its digestibility was responsible for the lower values of the second-cut silage. The hard stems in the second-cut silage were not eaten by the animals, and were treated as excrements in calculating the digestibility. The nitrogen balance was positive in the silage from both cuttings, but significantly higher in the first-cut silage. 
Table 14. Digestibility $(\%)$ and nitrogen balance of goat's rue silage (JAUHO 1984).

\begin{tabular}{lcc}
\hline Component & 1st cut & 2nd cut \\
\hline Dry matter & $71.7 \mathrm{a}$ & $54.5 \mathrm{~b}$ \\
Ash & $56.9 \mathrm{a}$ & $43.6 \mathrm{~b}$ \\
Organic matter & $73.0 \mathrm{a}$ & $55.4 \mathrm{~b}$ \\
Crude protein & $77.5 \mathrm{a}$ & $68.3 \mathrm{~b}$ \\
Fat & $64.2 \mathrm{a}$ & $57.4 \mathrm{~b}$ \\
Crude fibre & $66.9 \mathrm{a}$ & $41.6 \mathrm{~b}$ \\
Crude carbohydrates & $79.7 \mathrm{a}$ & $59.2 \mathrm{~b}$ \\
Nitrogen balance g & $5.12 \mathrm{a}$ & $1.27 \mathrm{~b}$ \\
\hline
\end{tabular}

The silage from the first cutting had the replacement value of $6.4 \mathrm{~kg} / \mathrm{fu}$ ( $\mathrm{kg}$ fodder/ feed unit, feed unit $=0.7 \mathrm{~kg}$ starch equivalent), which is approximately the same as for a good quality grass silage (SYRJÄLÄ and OJALA 1978). The replacement value for the secondcut silage was significantly higher $(10.6 \mathrm{~kg} / \mathrm{fu})$, partly because of the low dry matter content. The bulkiness in the first-cut silage was $1.3 \mathrm{~kg} / \mathrm{fu}$, whereas in the second-cut silage it was $1.7 \mathrm{~kg} / \mathrm{fu}$, because of the high fibre content. The protein content was $211 \mathrm{~g}$ and $253 \mathrm{~g}$ of soluble crude protein/fu in the first-cut and second-cut silage, respectively. Silage with a high protein content can thus be made even from late cuttings of goat's rue.

\subsubsection{Palatability of goat's rue silage}

The palatability of goat's rue silage was investigated at the Department of Animal Husbandry on December 13-26 in 1982 (JAUHO 1984). The experiment lasted only ten days, and two Finnish rams were used. The silage was made from the second cutting. The animals received enough silage for $10 \%$ left over. Minerals and water were also given (Table 15).

The daily voluntary intake was $9.53 \mathrm{~kg}$. The intake was $64.4 \mathrm{~g} / \mathrm{kg}$ metabolic live weight. Though this value is low, the animals gained weight during the experiment. The voluntary $\mathrm{DM}$ intake per $\mathrm{kg}$ live weight was $21.9 \mathrm{~g}$. This figure is low compared with the intake values for timothy silage.

The digestibility of this silage was low, $58.8 \%$, and the animals left the hard stems.
Table 15. Palatability of goat's rue silage. Second cut (JaUho 1984).

\begin{tabular}{lrrr}
\hline & Ram 1 & Ram 2 & x \\
\hline Voluntary intake of fresh & & & \\
silage g/d & 10210 & 8850 & 9530 \\
Voluntary intake of DM g/d & 1740 & 1500 & 1620 \\
g/kd W ${ }^{0.75 / d}$ & 68.9 & 59.8 & 64.4 \\
\hline
\end{tabular}

No evidence was observed that alkaloids lowered the palatability of the silage.

The protein content of goat's rue silage is high, but it should be cut early enough to avoid a high fibre content and low digestibility of stalks and stems.

\subsection{Fresh feeding and grazing}

Goat's rue is considered to be $15-20$ days earlier in development than red clover. Being high in protein content, a young goat's rue stand has a replacement value that is sufficient for high-production dairy cows without any additional fodder (RAIG 1980). However, the grazing tolerance of goat's rue and its palatability for cows have not been investigated.

\subsection{Hay}

Hay can also be made from goat's rue. Goat's rue hay has a replacement value of $1.6-1.8 \mathrm{~kg} / \mathrm{fu}$ and a protein content of $156-$ $198 \mathrm{~g}$ soluble crude protein/fu (JARTIJEVA 1977). In Estonia, artificial drying is recommended to assure curing and to avoid shedding of leaves. The early harvest of goat's rue can be considered an advantage in Finnish weather conditions.

\subsection{Protein concentrate}

Protein concentrate can be made from goat's rue. According to Estonian experiments, juice extracted from goat's rue contains $12 \%$ dry matter and $2.8 \%$ crude protein. The protein is easy to precipitate and is suitable for feeding cows, calves, pigs and hens (RAIG 1980). 
The leaf protein of goat's rue has also been investigated at the Department of Animal Husbandry in Helsinki (NÄsı and KIISKINEN 1985). Juice was extracted from fresh leaves and filtered through gauze. The substance collected on the gauze contained $52 \%$ crude protein. The in vitro digestibility of the leaf protein was $89.5 \%$, which is higher than in other legumes.

\section{Seed production}

Fairly good seed yields have been obtained from goat's rue in Estonia. There, goat's rue matures in the beginning of August, at a suitable time for combine harvesting. The recommended row spacing in Estonia is 60$90 \mathrm{~cm}$. The number of flowers and seeds are highest with this row spacing and weeds can be controlled mechanically or with herbicides (RAIG 1982).

In Finland, the seed production of goat's rue also seems to be reasonably successful. Only one year's results are available, but the seed used in field trials has been harvested in several years from a seed production plot. The seed has been ready for harvesting in August and the yield has varied from 300 to $500 \mathrm{~kg} / \mathrm{ha}$. The seed weight has been $6-7 \mathrm{~g} / 1000$ seeds and germination $80-90 \%$. Spacing of $25 \mathrm{~cm}$ seems to be better than $12.5 \mathrm{~cm}$. The leaves are usually green when the seed is mature, which allows spraying with diquat a few days before the harvest.

\section{Summary}

Goat's rue (Galega orientalis) is a perennial, unselected forage legume originating from regions with a Mediterranean climate. Research has mainly dealt with its general properties and its responses to management practices. The experience gained with goat's rue indicates that it can compete successfully with red clover in the quantity and quality of the yield, if the management takes account of its special growth pattern. The main advantage compared with red clover is its perenniality.
It spreads with underground stolons and grows best in light soils, evidently tolerating acid soil conditions fairly well. Of the alkaloids found in $G$. officinalis, only peganine has been detected in $G$. orientalis. The species has a specific Rhizobium strain, which is not related to those of the common temperate legumes. Goat's rue is cross-pollinating, is a good honey plant and has fairly good seed production.

The following recommendations can be made on the basis of the management trials carried out at the Department of Plant Husbandry of the University of Helsinki. Goat's rue should be sown early in the spring, with a seeding rate of $30 \mathrm{~kg} / \mathrm{ha}$. A seed mixture with timothy is possible, with $60-80 \%$ of goat's rue. As the early growth is slow, goat's rue is intolerant of cover crops and gives a low yield at the single cut in late September of the seeding year. In Finnish conditions, the number of cuts in later years should be restricted to two, to ensure good yields and to guarantee the development of underground stolon buds.

The first cut should be made during early flowering (second half of June), the second cut late in September. Mineral nitrogen is not necessary when the sward consists solely or predominantly of goat's rue, but small amounts of nitrogen can be given to mixtures with grasses during the first two years.

Goat's rue gives good raw material for silage when cut at the proper times. It has a high protein content, good digestibility and good palatability. The quality of the silage is somewhat impaired by the thick stems with their high fibre content and low digestibility. Mixtures of grass and goat's rue have not yet been investigated in feeding trials. Leaf protein production is also possible. The leaf extract has a high protein content and a very high digestibility.

So far, no pests or diseases have been discovered. Normal legume herbicides can be used for weed control.

\section{Literature}

Hegi, G. 1924. Industrierte Flora von Mittel-Europa. Band IV 3. Teil, 1388 p. München. 
JARTIJEVA, Z.A. 1977. Kormovaja tsennost i nekotorye priemy vozdelyvanija kozljatnika vostotšnogo (Galega orientalis Lam.) v uslovijah tsentralnyh rajonov netšernozemnoj Zony RSFSR. Autoreferat, M. 1977.

ЈАUно, M. 1984. Vuohenherne säilörehun raaka-aineena. Laudaturtyő, kotielăintieteen laitos. 66 p.

KANSANEN, P. 1983. Vuohenherne ja sen viljelytekniikka. Suomen Akatemian sopimustutkimuksen nro 383 loppuraportti. p. 93-126. Helsinki.

Komarov, V.L. 1963. Flora USSR: 303-304. Wiesbaden-Wehen $432 \mathrm{p}$.

KOHler, H. 1969. Die Prüfung von Galega-Arten auf ihren Gehalt an Giftsstoffen mit Hilfe biologischer Methoden. Biologisches Zentralblatt 88: 165-177.

LATTU, P. 1983. Kasvutiheyden ja niittojen vaikutus vuohenherneen satoon. Pro gradu -työ, kasvinviljelytieteen laitos. $68 \mathrm{p}$.

LindSTROM, K. 1984. Analysis of factors affecting in situ nitrogenase $\left(\mathrm{C}_{2} \mathrm{H}_{2}\right)$ activity of Galega orientalis, Trifolium pratense and Medicago sativa in temperate conditions. Plant and Soil 79: 329-341.

Lindstróm, K., Jarvis, B.W., Lindström, P.E. \& Patel, J.J. 1983. DNA homology, phage-typing, and crossnodulation studies of rhizobia infecting Galega species. Can. J. Microbiol. 29: 781-789.

Lindstróm, K., Sarsa, M.-L., Polkunen, J. \& Kansanen, P. 1985. Symbiotic nitrogen fixation on Rhizobium (Galega) in acid soils, and survival in acid and cold stress. Plant and Soil 87: 293-302.

Milne-Redhead, E. \& Polmill, R.M. (Ed.) 1971. Flora of Tropical East Africa. Part 4: 505-1108. London.

Măkărăinen, E., Kansanen, P., Kortesmaa, T. \& Varis, E. 1985. Rehuvuohenherneen viljelyominaisuudet ja käyttöarvo. Biologisen typensidonnan ja ravinnetypen hyvăksikăytön projekti. Suomen itsenaaisyyden juhlavuoden 1967 rahasto. Julkaisu 14, 72 p.

NÄSı, M. \& KIISKINEN, T. 1985. Leaf protein from green pulse crops and nutritive value of legume protein con- centrates for poultry. J. Agric. Sci. Finl. 57: 117-123. Proctor, H. \& Moustafa, E. 1962. Root nodules of Galega officinalis. New Zealand J. Sci. 5: 184-190.

Pufahl, K. \& Schreiber, K. 1963. Zum dünnschichtchromatographischen Nachweis von Inhaltstoffen der Geissraute, Galega officinalis. Züchter 33: 287-290.

RAIG, H. 1980. Söödagaleega kasvatamine ja kasutamine. Tallinna, Valgus. $64 \mathrm{p}$.

- 1982. Experience with newly introduced fodder plant - Galega orientalis Lam. - in the Estonian S.S.R. Tallinn. $15 \mathrm{p}$.

Regensburger, G. 1954. Ricerche sulla produttivita della capraggine (Galega officinalis) sottoporta a coltivazione. (Research of the productivity of goat's rue under cultivation), s. 512-514. Instituto Sperimentale Zootecnico, Roma.

RICHTER, E. 1968. Untersuchungen und Vorschläge zur Auslese von alkaloidarmen Pflanzen der Galega-arten durch chemische Massenselektion. Theor. Appl. Genetics 38: $118-122$.

SAlo, M.-L., TUORI, M. \& KIISKINEN, T. 1982. Rehutaulukot ja ruokintanormit, $70 \mathrm{~s}$. Helsinki.

Schreiber, K., Aurich, O. \& Pufahl, K. 1962. Isolierung von (+)-Peganin in Geissraute, Galega officinalis Lam. Archiv der Pharmazie 295: 271-275.

SCHÄFer, J. \& Stein, M. 1969. Untersuchungen über toxische Inhaltsstoffe bei Galega orientalis L. Biologisches Zentralblatt 88: 755-768.

SYrJĀlĀ, L. \& OJal.a, R. 1978. Kevăt- ja syyssadosta eri kehitysasteilla valmistetun timoteisăilörehun ravintoarvo. Kehittyvă Maatalous 39: 36-49.

Tutin, T.G., Heywood, V.H., Burges, N.A. et al. 1968. Flora Europaea. Vol 2: 107. Cambridge 454 p.

Willis, J.C. 1973. A Dictionary of the Flowering Plants and Ferns. 8 ed. Cambridge 1245 p.

Ms received September 8, 1986 


\title{
YHTEENVETO
}

\section{Rehuvuohenherne (Galega orientalis Lam.), mahdollinen monivuotinen lauhkean vyöhykkeen rehukasvi}

\author{
Eero Varis \\ Helsingin yliopisto, Kasvinviljelytieteen laitos \\ 00710 Helsinki
}

Rehuvuohenherne (Galega orientalis Lam.) on Välimeren ilmastoalueelta peräisin oleva monivuotinen, jalostamaton rehukasvi. Sen yleisiä viljelyominaisuuksia ja myös viljelytekniikkaa on tutkittu. Saatujen tulosten ja kokemusten pohjalta voidaan sanoa sen menestyksellisesti kilpailevan puna-apilan kanssa sekä sadon määrän ettă laadun suhteen, kunhan sitä viljelläăn sen oman kasvuja kehitysrytmin mukaisesti. Sen suurin etu puna-apilaan verrattuna on sen pitkäikäisyys. Se leviaaă maanalaisin rönsyin ja viihtyy parhaiten keveillă mailla. Se năyttaaă kestăvăn maan happamuutta melko hyvin. Rohtovuohenherneestă (G. officinalis, L.) tavatuista alkaloideista rehuvuohenherneestä on löydetty vain peganiinia. Vuohenherneellă on oma Rhizobium-kantansa, joka ei ole sukua muille lauhkean ilmaston ritsobeille. Se on ristisiittoinen laji, hyvä hunajakasvi ja siemenen saanti on suhteellisen helppoa.

Tässä raportissa selostetaan Helsingin yliopiston kasvinviljelytieteen laitoksella suoritettuja vuohenherneen viljelyteknillisiä kokeita. Kevătkylvő 30 kg:n siemenmaaărää kåyttäen näyttäă suositeltavalta kylvötavalta. Siemenseos timotein kanssa, jossa on $60-80 \%$ vuohenhernettä, näyttaă mahdolliselta. Vuohenherne kehittyy kylvövuonna hitaasti, ja ilmankin suojaviljaa, mită se ei năytă sietăvăn,

se tuottaa kylvövuonna vain yhden vaatimattoman sadon syyskuun lopulla. Suomen kasvuoloissa kaksi niittoa seuraavina vuosina näyttäă riittävăltă runsaan, hyvălaatuisen sadon saamiseksi ja maanalaisten rönsyjen kasvusilmujen kehityksen turvaamiseksi.

Ensimmäinen niitto suositellaan kukinnan alkuvaiheessa kesăkuun loppupuoliskolla, toinen niitto syyskuun loppupuolella. Typpilannoitus ei ole tarpeen puhtaalle tai vuohenhernevaltaiselle nurmelle, lukuunottamatta seosnurmea parina ensimmäisenă vuotena, jolloin pieni mäărä typpeă piristaă timotein kasvua.

Vuohenherneestă saadaan sopivia niittoaikoja kãyttăen hyvăă sảilörehun raaka-ainetta. Sillă on korkea valkuaispitoisuus, hyvă sulavuus ja myös hyvă maittavuus. Paksut varret ja niiden korkea kuitupitoisuus heikentävät jonkin verran rehun laatua. Seosnurmien laatua ei ole testattu ruokintakokein. Lehtiproteiinin valmistus vuohenherneestä on myös mahdollista. Lehtiuutteen valkuaispitoisuus ja sen sulavuus ovat hyvin korkeat. Muuta rehukäyttöă ei ole tutkittu.

Tăhän mennessä vuohenherneestä ei ole tavattu tauteja eikả tuholaisia. Se kestäă samoja herbisidejä kuin muutkin palkokasvit. 
ERRATA: Varis, E. 1986. Goat's rue (Galega orientalis, Lam.), a potential pasture legume for temperature conditions. Vol. 58: 83-101, 1986.

Table 7. Total DM yield $(\mathrm{kg} / \mathrm{ha})$ from goat's rue leys in $1983-85$.

\begin{tabular}{|c|c|c|c|c|c|}
\hline \multirow{2}{*}{$\begin{array}{l}\text { Cutting } \\
\text { time in } \\
\text { the autumn }\end{array}$} & \multicolumn{4}{|c|}{ Cutting time in the summer } & \multirow[b]{2}{*}{$\bar{X}$} \\
\hline & 4. 6. & 11. 6 . & 19. 6. & 28.6. & \\
\hline 24. 8 . & 12510 & 16170 & 14560 & 16250 & 14860 a \\
\hline 7. 9. & 17030 & 16710 & 21400 & 22660 & $19450 \mathrm{~b}$ \\
\hline 16. 9. & 15360 & 18900 & 20360 & 22080 & $19180 \mathrm{~b}$ \\
\hline 5. 10. & 14830 & 18510 & 20190 & 20830 & $18570 \mathrm{~b}$ \\
\hline $\bar{X}$ & $\begin{array}{c}14930 \\
a\end{array}$ & $\begin{array}{c}17570 \\
a b\end{array}$ & $\begin{array}{c}19110 \\
a b\end{array}$ & $\begin{array}{c}20450 \\
b\end{array}$ & 18020 \\
\hline F-value & \multicolumn{5}{|c|}{$\begin{array}{l}\text { Summer cut } * * \text { HSD } 0.01=4570 \mathrm{KG} \\
\text { Autumn cut } * * * \text { HSD } 0.001=1690 \mathrm{KG}\end{array}$} \\
\hline
\end{tabular}

